\title{
The digestion and absorption of protein in man
}

\author{
1. The site of absorption
}

\author{
By S. ELIZABETH NIXON* AND G. E. MAWER \\ Department of Therapeutics, University of Edinburgh
}

(Received 6 Fune 1969-Accepted 2 October 1969)

\begin{abstract}
I. The absorption of the amino acid components of two protein-containing test meals has been studied in six healthy volunteers. One meal contained $15 \mathrm{~g}$ of milk protein and the other contained $15 \mathrm{~g}$ of gelatin. In a control experiment a meal was given which contained a negligible amount of protein.

2. The subjects were intubated with a single lumen tube; then each meal was swallowed and intestinal residues were obtained from known levels. The amino acid composition of the intestinal contents was compared with that of the original meal. Correction was made for net water shifts by reference to a non-absorbable marker compound (polyethylene glycol 4000).

3. The results showed that at least $70-75 \%$ of the milk protein test meal had been absorbed when the sampling holes were $230 \mathrm{~cm}$ from the nose. It is suggested, however, that most, if not all, of the meal had been absorbed when the sampling holes were $140 \mathrm{~cm}$ from the nose.

4. Amino acids were absorbed at rates proportional to their concentrations in the meal.

5. Gelatin, a protein known to be relatively resistant to enzymic hydrolysis, was poorly absorbed from the region of the small intestine under study.

6. Estimates of the amount of endogenous protein secreted in response to the test meals ranged from 2 to $8 \mathrm{~g}$, equivalent to $\mathrm{I} 3-53 \%$ of the protein containing test meals.

7. The absorption of certain amino acids, e.g. the dicarboxylic amino acids, was more rapid than was expected; glutamic and aspartic acids are absorbed slowly from a mixture of amino acids, both in vitro and in vivo.
\end{abstract}

Borgström, Dahlqvist, Lundh \& Sjövall (1957) showed that absorption of protein in man begins in the distal part of the duodenum and is about $80 \%$ completed in the first $50-100 \mathrm{~cm}$ of jejunum. In their experiments a test meal incorporating ${ }^{131} \mathrm{I}$-labelled human serum albumin was fed to human subjects and protein absorption was calculated from the amounts of ${ }^{131} \mathrm{I}$ activity in aspirated samples. The labelled serum albumin constituted a very small percentage of the total protein in the test meal, and it was assumed that the results describing the rates of digestion and absorption of the labelled protein could be extrapolated to describe the fate of the major part of the test protein.

The use of ${ }^{131} \mathrm{I}$-labelled albumin as an index of absorption of dietary protein may be criticized. The presence of the iodine label could interfere with both enzymic hydrolysis and amino acid absorption. The present study was done in order to determine the site of absorption of dietary protein with physiological proteins as the test meals.

Two protein-containing test meals (milk protein and gelatin) of known amino acid composition were fed to intubated human subjects and the net absorptions of the amino acid residues at various levels of the small intestine were determined. An intestinal marker, polyethylene glycol 4000 , was incorporated into the test meals and amino acid concentrations were determined relative to this in the test meals and in the

* Present address: Stracathro Hospital, Brechin, Angus, Scotland. 
intestinal samples. The efficacy of polyethylene glycol as a marker in such studies has been shown by various workers (Borgström et al. 1957; Maddrey, Serebro, Marcus \& Iber, 1967). The analysis of intestinal samples after a low-protein meal provided a base-line for the studies.

The work suggests that the absorption of the amino acid components of milk protein approaches completion within the first $40-50 \mathrm{~cm}$ of jejunum. Amino acids are absorbed at rates proportional to their concentrations in the test meal. The amino acids secreted into the upper gastro-intestinal tract as protein, peptide or amino acid did not exceed the amount present in the milk protein meal.

\section{EXPERIMENTAL}

\section{Procedure}

Only a brief description of the methods is given here. The techniques used are described in more detail in a previous paper (Mawer \& Nixon, I969).

The subjects who volunteered for the experiments (five men and one woman) were normal young adults, aged $2 \mathrm{I}-34$ years. All six subjects took the milk-protein test meal. Two of the subjects, in separate experiments, took the gelatin meal and the lowprotein meal. At least two experiments were performed on each subject.

The subjects were intubated with a single lumen tube (internal diameter $\mathrm{I} \cdot 6 \mathrm{~mm}$, external diameter $2.45 \mathrm{~mm}$ ) according to the method of Blankenhorn, Hirsch 8 Ahrens (1955). The test meal was taken when the sampling holes reached the level of the duodenum or upper jejunum and again when they reached the level of the lower jejunum. The length of the tube between the nose and the sampling holes was determined at the beginning and the end of each experiment and the mean of these values was taken as the level for that experiment. Before an experiment the subjects were fasted for at least $4 \mathrm{~h}$ and usually overnight.

Intestinal samples were collected by continuous siphonage during the $3 \mathrm{~h}$ period immediately following the ingestion of the meal. The amino acid content of the test meals and of the intestinal samples was determined by acid hydrolysis under nitrogen followed by ion exchange chromatography on an EEL Automatic Amino Acid Analyser. The possible losses of amino acids during the hydrolysis procedure were estimated in five recovery experiments (Mawer \& Nixon, I969). The polyethylene glycol (PEG) concentrations in the intestinal contents were determined by the turbidimetric method of Hydén (1956).

\section{Test meals}

The protein-containing test meals were intended to simulate normal meals with regard to protein, fat and carbohydrate content. The three test meals were designed to differ only in protein content.

The milk-protein meal. The meal consisted of $400 \mathrm{ml}$ of an emulsion prepared from I $00 \mathrm{~g}$ of Humanized Trufood (Trufood Ltd) and 2.0 $\mathrm{g}$ of PEG in distilled water. The $\mathrm{pH}$ of the meal was $6 \cdot 4$.

The gelatin meal. ${ }_{5} \mathrm{~g}$ of gelatin (BP grade), $\mathrm{I}_{5} \mathrm{ml}$ stock salt solution, $53 \mathrm{~g}$ lactose 
and $2.0 \mathrm{~g}$ PEG were dissolved in hot distilled water. This was allowed to cool slightly and $7 \mathrm{I} \mathrm{g}$ of double cream were added by stirring. The volume was made up to $400 \mathrm{ml}$ with distilled water, the $\mathrm{pH}$ adjusted to that of the milk-protein meal by the addition of concentrated $\mathrm{HCl}$ and the meal was taken as a lightly set jelly.

The stock salt solution was made up as follows: $35.73 \mathrm{~g}$ calcium gluconate, $2 \cdot 7 \mathrm{I} \mathrm{g} \mathrm{NaCl}_{1} \cdot 5^{2} \mathrm{~g} \mathrm{KCl}$, I I.22 $\mathrm{g} \mathrm{KHCO}_{3}$, I7.90 $\mathrm{g} \mathrm{Na}_{2} \mathrm{HPO}_{4}$. I $2 \mathrm{H}_{2} \mathrm{O}, 7 \cdot 80 \mathrm{~g} \mathrm{NaH}_{2} \mathrm{PO}_{4}$. $2 \mathrm{H}_{2} \mathrm{O}$ and $3.92 \mathrm{~g} \mathrm{MgCl}_{2} \cdot 6 \mathrm{H}_{2} \mathrm{O}$ were each dissolved individually then mixed, and the

\section{Table I. Composition of the test meals}

(Quantities per meal: volume, $400 \mathrm{ml}$ )

\begin{tabular}{|c|c|c|c|c|c|c|c|}
\hline \multirow[b]{2}{*}{ Constituent } & \multicolumn{3}{|c|}{$\mathrm{g}$} & & \multicolumn{3}{|c|}{ m-moles } \\
\hline & MP & $\mathrm{G}$ & $\mathbf{L P}$ & & MP & G & $\mathbf{L P}$ \\
\hline Lactose & 53 & 54 & 54 & Glu & I 8 & Io & 0.60 \\
\hline Fat & 24 & 26 & 26 & Leu & 10 & $3 \cdot 6$ & 0.62 \\
\hline \multirow[t]{7}{*}{ PEG } & 2.0 & $2 . c$ & 2.0 & Asp & $9 \cdot 3$ & $6 \cdot 3$ & 0.42 \\
\hline & & & & Pro & $8 \cdot 5$ & I 6 & 0.50 \\
\hline & & & & Ser & $7 \cdot 2$ & $5 \cdot 1$ & 0.48 \\
\hline & & & & Val & $7 \cdot 0$ & $3 \cdot 3$ & 0.54 \\
\hline & & & & Thr & $6 \cdot 8$ & $2 \cdot 6$ & 0.38 \\
\hline & \multicolumn{3}{|c|}{ m-equiv. } & Lys & $6 \cdot 8$ & 3.7 & 0.40 \\
\hline & & & & Ala & $6 \cdot 4$ & 16 & 0.30 \\
\hline Sodium & 44 & 42 & 47 & Ileu & $5 \cdot 8$ & $1 \cdot 9$ & $0.3^{8}$ \\
\hline Potassium & 46 & 46 & 48 & Gly & $3 \cdot 9$ & 46 & 0.34 \\
\hline Calcium & $3^{8}$ & 29 & 25 & Phe & $3 \cdot 5$ & $\mathrm{I} \cdot 8$ & 0.28 \\
\hline Magnesium & 9 & 4 & 4 & Tyr & $2 \cdot 8$ & 0.30 & 0.16 \\
\hline \multirow[t]{6}{*}{ Chloride } & 39 & 39 & 45 & Arg & $2 \cdot 1$ & 4.9 & 0.22 \\
\hline & & & & $\mathrm{His}$ & $2 \cdot 0$ & 0.80 & 0.26 \\
\hline & & & & Met & $\mathbf{I} \cdot 9$ & 0.14 & 0.12 \\
\hline & & & & Cys & 0.66 & $c \cdot 30$ & 0.04 \\
\hline & & & & Hyp & 0.0 & 12 & 0.0 \\
\hline & & & & Total & $10_{3}$ & I 34 & $6 \cdot 0$ \\
\hline
\end{tabular}

MP, milk-protein meal; G, gelatin meal; LP, low-protein meal. The amino acid values for the gelatin meal include those derived from the cream.

total volume was made up to $500 \mathrm{ml}$. Insoluble salts of calcium and magnesium precipitated as a fine suspension. The cream contributed only trace amounts of electrolytes to the meal.

The low-protein meal. This meal was prepared by excluding gelatin from the above meal. A low-protein meal was used in preference to a protein-free meal because of the difficulties of producing the latter in a homogenous and palatable form.

The three meals were analysed for reducing sugar by a standard automatic ferricyanide method with lactose as standard. The presence of other reducing substances was not ruled out. Triglyceride was estimated by periodate oxidation of the glycerol produced by alkaline hydrolysis (Carlson \& Wadstrom, 1959). Insignificant amounts of monoand di-glycerides were present. Amino acid content was measured by ion exchange chromatography after acid hydrolysis. $\mathrm{Na}^{+}$and $\mathrm{K}^{+}$were estimated by flame photometry, $\mathrm{Ca}^{2+}$ and $\mathrm{Mg}^{2+}$ by atomic absorption spectrophotometry and chloride by the back titration of standard silver nitrate. 
The composition of the three meals is shown in Table $\mathrm{I}$. With the exception of the protein content, the meals differed only slightly in composition. The lower concentrations of $\mathrm{Ca}^{2+}$ and $\mathrm{Mg}^{2+}$ in the gelatin and the low-protein meals may have been due to loss of precipitate on glassware during preparation.

\section{Calculation of the amino acid concentrations}

The amino acid concentrations of $3 \mathrm{~h}$ collections of intestinal samples were calculated in order to minimize those differences between subjects that were due to different rates of transit of the test meal. It was assumed that the amino acid composition of a sample collected over $3 \mathrm{~h}$ at any level was representative of the composition of the complete PEG-containing bolus as it passed the sampling level. The ratios of amino acids to PEG $(\mu \mathrm{moles} / \mathrm{mg})$ in the complete $3 \mathrm{~h}$ collection period were calculated from the following expression:

$$
\frac{\sum_{0}^{3 \mathrm{~h}} \text { Amino acid concentration }(\mu \mathrm{moles} / \mathrm{ml}) \times \text { volume }(\mathrm{ml})}{\sum_{0}^{3 \mathrm{~h}} \text { PEG concentration }(\mathrm{mg} / \mathrm{ml}) \times \text { volume }(\mathrm{ml})} .
$$

RESULTS

\section{The total amino acid concentrations}

Table 2 shows the total concentration of amino acids (the sum of the concentrations of each amino acid measured) in each meal and the mean concentrations in samples of intestinal contents. The numbers in parentheses are the numbers of experiments at each level.

Although absorption predominated after the protein meals and secretion predominated after the low-protein meal, both processes may be assumed to have occurred concurrently in each instance. In the duodenum, after the milk-protein meal, the two processes were almost equal. After each of the protein meals net absorption was observed along the segment of gut between the duodenum $(80-88 \mathrm{~cm})$ and the upper jejunum $(96-120 \mathrm{~cm})$ and between this level and the lower level $(137-240 \mathrm{~cm})$. After the low-protein meal, however, net secretion was evident at both levels of jejunum.

If the amino acid content of the low-protein meal is neglected, the mean amino acid concentration measured in the samples from the 96-120 cm level after this meal ( $44 \mu$ moles/mg PEG) represents a minimum estimate of endogenous amino acids. This is of a similar order to the increase in concentration observed in the duodenum after the gelatin test meal.

This value of $14 \mu$ moles/mg PEG at least should be added to the total amino acid concentrations of the protein meals when deriving a minimum estimate of total amino acid absorbed. Thus, after the milk-protein meal, at least $(53+14)-42=25 \mu-$ moles amino acid per mg PEG were absorbed between the stomach and the upper jejunum. This is equivalent to approximately $50 \%$ of the milk-protein test meal. 
Concentrations of individual amino acids

The amino acid concentration refers to the concentration of each $\alpha$-amino acid released by acid hydrolysis over a period of $18 \mathrm{~h}$. The term includes the concentration of the $\alpha$-amino acid in the free state as well as the concentration of peptide-linked amino acid.

Table 2. Mean concentrations ( $\mu$ moles/mg PEG) of the total amino acids in the test meals and in samples collected from the intestines of young adults during the $3 h$ following the ingestion of the meals

(Numbers in parentheses are the numbers of experiments which were done at each level)

$\begin{array}{lcccc}\text { Meal } & \begin{array}{c}\text { Concentration } \\ \text { in meal }\end{array} & \begin{array}{c}\text { Concentration in samples at distance } \\ \text { from nose of }\end{array} \\ \text { Milk-protein } & 53 & 56(4) & 42(5) & 22(9) \\ \text { Gelatin } & 67 & 84(2) & 57(2) & 40(2) \\ \text { Low-protein } & 3 & - & 14(2) & 10(3)\end{array}$

Table 3. Influence of the level of sampling on the amino acid concentrations (umoles/mg $P E G)$ in 3 collections of contents from the intestines of young adults after a milk-protein meal

\begin{tabular}{|c|c|c|c|c|c|}
\hline \multirow[b]{2}{*}{$\begin{array}{l}\text { Amino } \\
\text { acid }\end{array}$} & \multirow[b]{2}{*}{$\begin{array}{c}\text { Concentration in } \\
\text { meal }\end{array}$} & \multicolumn{4}{|c|}{$\begin{array}{c}\text { Concentration in samples at distances } \\
\text { from nose of }\end{array}$} \\
\hline & & $80-88 \mathrm{~cm}$ & $96-120 \mathrm{~cm}$ & $139 \mathrm{~cm}$ & I $50-245 \mathrm{~cm}$ \\
\hline Asp & 4.7 & $5 \cdot 2$ & $4 \cdot I$ & $2 \cdot 4$ & $2 \cdot 3$ \\
\hline Thr & $3 \cdot 4$ & $3 \cdot 7$ & $2 \cdot 7$ & $1 \cdot 6$ & $I \cdot 5$ \\
\hline Ser & $3 \cdot 6$ & $4 \cdot 1$ & 2.9 & $\mathrm{I} \cdot 8$ & I.7 \\
\hline Pro & 4.3 & 47 & $3 \cdot 2$ & $1 \cdot 9$ & $\mathrm{I} \cdot 7$ \\
\hline Glu & $9 \cdot 0$ & $8 \cdot 3$ & $6 \cdot 2$ & 3.7 & $3 \cdot 2$ \\
\hline Gly & 2.0 & 6.9 & $6 \cdot 5$ & 2.7 & $4: 3$ \\
\hline Ala & $3 \cdot 4$ & $3 \cdot \mathbf{I}$ & $2 \cdot 5$ & $1 \cdot 2$ & $I \cdot 4$ \\
\hline Cys & 0.33 & 0.50 & $0.4 \mathrm{I}$ & 0.27 & 0.26 \\
\hline Val & 3.5 & $3 \cdot 6$ & $2 \cdot 4$ & $1 \cdot 4$ & $1 \cdot 3$ \\
\hline Met & 0.92 & 0.77 & 0.53 & 0.26 & 0.21 \\
\hline Ileu & $2 \cdot 9$ & $2 \cdot 8$ & $1 \cdot 9$ & $1 \cdot 0$ & $I \cdot 0$ \\
\hline Leu & 5.0 & $4 \cdot 6$ & $3 \cdot 3$ & $1 \cdot 6$ & $I \cdot 5$ \\
\hline Tyr & $\mathrm{I} \cdot 4$ & $\begin{array}{l}40 \\
1 \cdot 5\end{array}$ & $\begin{array}{l}5.5 \\
I \cdot 4\end{array}$ & 0.63 & 0.52 \\
\hline Phe & $\mathrm{I} \cdot 8$ & $I \cdot 7$ & $1 \cdot 2$ & 0.82 & 0.65 \\
\hline Lys & $3 \cdot 4$ & $3 \cdot 4$ & $2 \cdot 6$ & $I \cdot 4$ & $I \cdot 2$ \\
\hline $\mathrm{His}$ & $1 \cdot 0$ & $1 \cdot 0$ & 0.85 & 0.50 & 0.42 \\
\hline Arg & $I \cdot I$ & $1 \cdot 2$ & 0.85 & 0.46 & 0.42 \\
\hline
\end{tabular}

The values are means from four experiments at $80-88 \mathrm{~cm}$ from the nose, five experiments at $96-$ $120 \mathrm{~cm}$, one experiment at $139 \mathrm{~cm}$ and eight experiments at $150-245 \mathrm{~cm}$. The amino acid composition of the test meal is included in the table for comparison.

Table 3 shows the influence of the level of sampling on the amino acid concentrations in intestinal samples after a milk-protein meal. For comparison the concentrations of amino acids in the test meal are included in the table.

The concentrations in the duodenum ( $80-88 \mathrm{~cm}$ from the nose) were, in general, very little different from those in the test meal. Some amino acids, e.g. glutamic acid, alanine and leucine, decreased slightly in concentration whereas others, e.g. aspartic 
acid, threonine and serine increased slightly. The concentration of glycine had trebled. The amino acid concentrations, with few exceptions, decreased steadily at increasing distances from the duodenum. The fall in concentration was steepest between 86 and $139 \mathrm{~cm}$ from the nose. Between 86 and $139 \mathrm{~cm}$ a total of $30 \mu$ moles $/ \mathrm{mg}$ PEG (excluding glycine) were absorbed, equivalent to $0.55 \mu$ moles $/ \mathrm{mg}$ PEG per $\mathrm{cm}$ gut. The corresponding values for the segments of gut, $139-170$ and $170-245 \mathrm{~cm}$ were 0.14 and 0.18 $\mu$ mole $/ \mathrm{mg}$ PEG per cm gut. At levels below $100 \mathrm{~cm}$ from the nose the concentrations of all the amino acids, with the exception of glycine, were lower than those in the meal. The glycine concentration varied but remained consistently greater than that in the meal.

Table 4. Influence of the level of sampling on the amino acid concentrations ( $\mu$ moles/mg $P E G)$ in 3 collections of contents from the intestines of young adults after a gelatin meal

\begin{tabular}{|c|c|c|c|c|}
\hline \multirow[b]{2}{*}{ Amino acid } & \multirow{2}{*}{$\begin{array}{c}\text { Concentration in } \\
\text { meal }\end{array}$} & \multicolumn{3}{|c|}{$\begin{array}{c}\text { Concentration in samples at distance } \\
\text { from nose of }\end{array}$} \\
\hline & & $8 z-85 \mathrm{~cm}$ & I $13-126 \mathrm{~cm}$ & $185-194 \mathrm{~cm}$ \\
\hline Asp & $3 \cdot 2$ & $5 \cdot 1$ & $3 \cdot 5$ & $2 \cdot 7$ \\
\hline Thr & $I \cdot 3$ & $1 \cdot 9$ & $I \cdot 5$ & $I \cdot 2$ \\
\hline Ser & $2 \cdot 6$ & $4 \cdot 0$ & $2 \cdot 4$ & $I \cdot 7$ \\
\hline Pro & 8.0 & $8 \cdot 8$ & $6 \cdot 3$ & 4.5 \\
\hline Glu & $5 \cdot 0$ & 6.9 & $5 \cdot 7$ & $3 \cdot 4$ \\
\hline Gly & $22 \cdot 9$ & $27 \cdot 5$ & 19.5 & $13 \cdot 2$ \\
\hline Ala & $8 \cdot 0$ & $8 \cdot 7$ & $5 \cdot 6$ & $3 \cdot 6$ \\
\hline Val & $1 \cdot 7$ & $2 \cdot 5$ & $1 \cdot 7$ & $I \cdot I$ \\
\hline Met & 0.07 & 0.52 & 0.29 & 0.19 \\
\hline Ileu & 1.0 & $x \cdot 5$ & 1.0 & 0.73 \\
\hline Leu & $\mathrm{I} \cdot 8$ & $3 \cdot I$ & $1 \cdot 7$ & $I \cdot 3$ \\
\hline Tyr & 0.15 & 0.67 & 0.50 & 0.44 \\
\hline Phe & 0.91 & $1 \cdot 3$ & 0.91 & 0.65 \\
\hline Lys & $I \cdot 9$ & $2 \cdot 5$ & $1 \cdot 6$ & $I \cdot I$ \\
\hline $\mathrm{His}$ & 0.39 & 0.52 & 0.45 & 0.39 \\
\hline Arg & $2 \cdot 5$ & $2 \cdot 8$ & $1 \cdot 4$ & 0.76 \\
\hline Hyp & 5.9 & $5 \cdot 4$ & $4 \cdot 2$ & $3 \cdot 2$ \\
\hline
\end{tabular}

Each value is the mean of two experiments done at that level. The amino acid composition of the test meal is included in the table for comparison.

'Table 4 shows the relationship between the level of sampling and the amino acid concentrations after the gelatin meal. Again the decrease in concentration was greatest in the upper part of the jejunum. In the duodenum the concentrations of most of the amino acids were considerably greater than those in the test meal; even at a level of I $3 \mathrm{~cm}$ from the nose the concentrations of all the amino acids with the exceptions of proline, hydroxyproline, alanine and arginine were still greater than those in the meal. At no time were the concentrations of methionine or tyrosine less than the low levels given.

Table 5 shows the relationship between the amino acid concentrations in the lowprotein test meal and those in the intestinal samples obtained from different levels. There was a clear decrease with level of sampling, though this was less than the decrease for the milk-protein meal. 
Table 5. Influence of the level of sampling on the amino acid concentrations ( $\mu$ moles/mg $P E G)$ in 3 collections of contents from the intestines of young adults after a low-protein meal

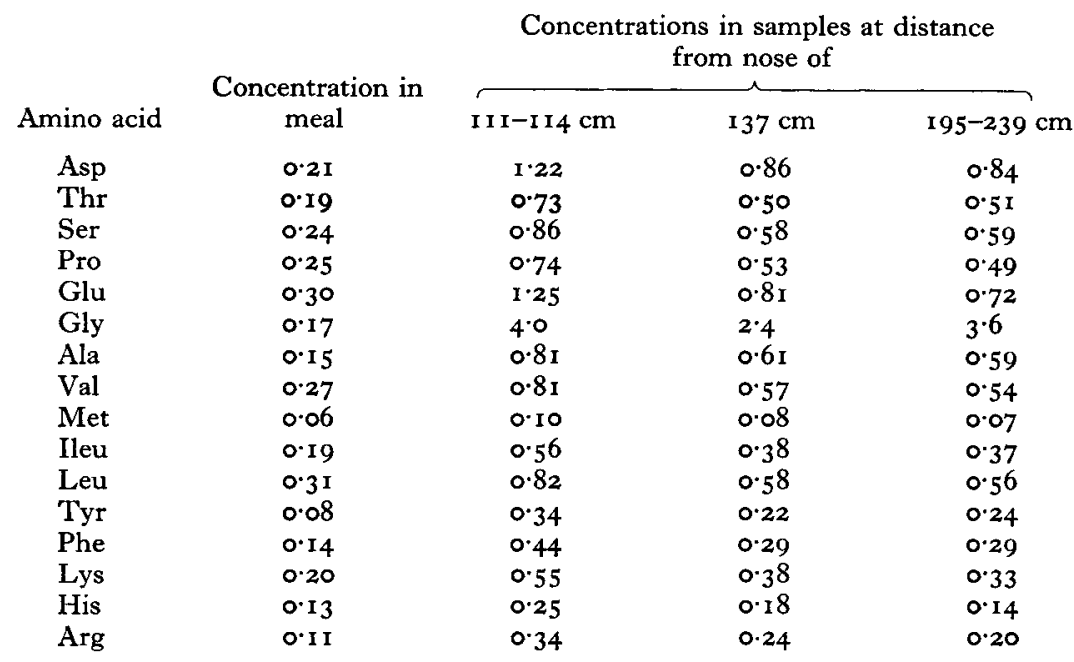

The values are the means of two experiments at III and II $4 \mathrm{~cm}$ from the nose, one experiment at $137 \mathrm{~cm}$ and two experiments at 195 and $239 \mathrm{~cm}$. The amino acid composition of the meal is included in the table for comparison.

\section{Glycine and taurine concentrations in intestinal samples}

The hydrolysates of intestinal samples contained high concentrations of glycine and taurine, the concentrations varying with the individual. In samples from upper intestinal levels the glycine concentrations ranged from $7 \cdot 2$ to $14 \cdot 2 \mu \mathrm{moles} / \mathrm{ml}$ after a milk-protein meal. The range for samples from the lower level was from $6 \cdot 1$ to $12 \cdot 0$ $\mu \mathrm{moles} / \mathrm{ml}$. The taurine concentrations in samples from the upper level ranged from $\mathrm{I} \cdot 2$ to $3 \cdot \circ \mu \mathrm{moles} / \mathrm{ml}$ and in samples from the lower level, from $\mathrm{I} \cdot 7$ to $3.8 \mu \mathrm{moles} / \mathrm{ml}$.

Taurine was present entirely in a conjugated form and $90-98 \%$ of the glycine was conjugated, even after the gelatin meal. No taurine was detected in hydrolysates of the test meals. The ratio of the concentration of glycine to that of taurine in samples taken after the milk-protein meal and the low-protein meal was $3.7 \pm 0.5$ (mean \pm standard error). The relative concentrations in the samples after the gelatin meal were much higher, presumably because of the much larger amounts of glycine given in the meal.

It is probable that this addition of glycine and taurine to intestinal contents was from bile salts. The ratio of glycine-conjugated to taurine-conjugated bile acids in human jejunal contents ranged from $x^{\cdot} 3$ to $6 \cdot 3$ in the experiments described by Börgstrom and his colleagues (Sjövall, 1959). Some glycine must also have been derived from endogenous protein.

The combined glycine and taurine concentrations represented a significant percentage of the total amino acids plus taurine in intestinal contents. The sum of the concentrations of glycine and taurine expressed as a percentage of the total concentrations 
of the amino acids plus taurine in the samples after the milk-protein meal ranged from I 5 to $20 \%$ at the upper level and from I 8 to $26 \%$ at the lower level. The corresponding values in the two subjects given the low-protein meal were 20 and $40 \%$ in samples from the upper level and $38-45 \%$ in samples from the lower level.

In the determination of protein amino acids in intestinal contents by nitrogen estimation or by the ninhydrin method, using unfractionated material, a considerable error may therefore be introduced by the presence of these bile salts, especially in intestinal samples after a low-protein or protein-free meal.

\section{$p H$ of the intestinal samples}

The mean values for the $\mathrm{pH}$ of the samples collected from the upper levels after the milk-protein meal was $5 \% 75$. In every experiment the $\mathrm{pH}$ fell with succeeding hourly collections. The mean values for each hourly collection from the upper levels were $6 \cdot 28$ (range $5 \cdot 94^{-7} \cdot 32$ ), $5 \cdot 74$ (range $5 \cdot 4^{1-6} \cdot{ }^{1} 3$ ) and $5 \cdot 21$ (range $4 \cdot 60-6 \cdot 00$ ). The $\mathrm{pH}$ values of the samples collected from the lower level were less affected by the time of collection. The mean value in these samples after the milk-protein meal was $6 \cdot 28$ (range $5 \cdot 95^{-6} \cdot 69$ ).

The $\mathrm{pH}$ values of the samples collected after the other two meals were similar to those after the milk-protein meal.

\section{DISCUSSION}

\section{Degree of net absorption}

The amino acid concentrations in the intestinal samples are the net result of secretion and absorption. That some absorption had already occurred in the duodenum after the milk-protein meal is evident from the lower concentrations of glutamate, leucine and methionine in the duodenal samples compared with those in the test meal. When the sampling holes were $100 \mathrm{~cm}$ from the nose, a net disappearance of $30 \%$ of the amino acids of the milk-protein meal (excluding glycine) had occurred: at $245 \mathrm{~cm}$ a net disappearance of $75 \%$ had occurred.

The gelatin meal was less well absorbed. At $194 \mathrm{~cm}$ from the nose the net disappearance was only $30 \%$ of the amino acids present in the meal. Tyrosine and methionine showed net secretion and the concentration of histidine was unchanged from that in the meal. A large proportion of many of the amino acids in the gut after the gelatin meal may have been of endogenous origin and less susceptible to digestion and absorption than dietary protein. However hydroxyproline, purely of dietary origin, showed an absolute absorption of only $46 \%$ in samples collected from the intestine, $195 \mathrm{~cm}$ from the nose. The poorer absorption of gelatin in these experiments is in agreement with the findings of Rogers and his colleagues (Rogers, Chen, Peraino \& Harper, I960) They found that the nitrogen content of the small intestinal contents of the rat was greater after a gelatin meal than after a casein meal.

\section{Site of absorption of dietary proteins}

The results suggest that the major part of the digestion and absorption of dietary proteins takes place within the duodenum and upper jejunum proximal to a level of 
$140 \mathrm{~cm}$ from the nose. The following observations are consistent with this as a hypothesis.

(I) In the duodenum, absorption after the milk-protein meal was almost entirely masked by secretion, but as the sampling point passed from the duodenum down the upper jejunum the amino acid concentrations fell steeply (Table 3 ). Below $140 \mathrm{~cm}$

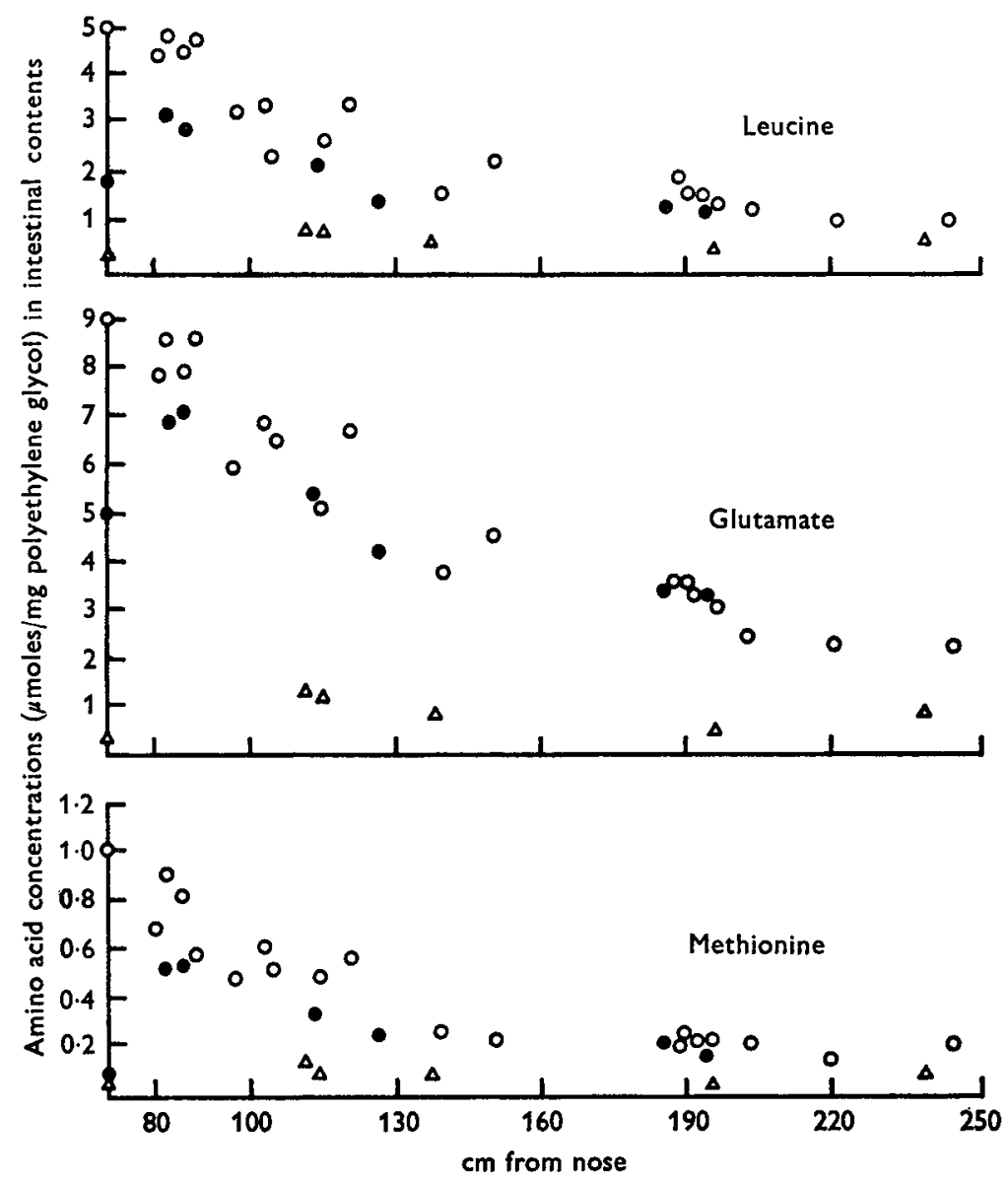

Fig. I. Concentrations of leucine, glutamate and methionine in acid hydrolysates of $3 \mathrm{~h}$ collections of intestinal contents collected from various levels of the small intestine of young adults after the three test meals. Each point is the result from one experiment. The points on the ordinates indicate the concentrations in hydrolysates of the test meals. $O$, after milk-protein meal; after gelatin meal; $\triangle$, after low-protein meal.

the concentrations continued to fall much more gradually. These results would be explained if amino acid or peptide absorption below $140 \mathrm{~cm}$ was retarded by the relative resistance of endogenous protein to proteolysis.

(2) The concentrations of leucine, glutamate and methionine in the two protein meals and in the intestinal contents were compared (Fig. r). After the milk-protein meal the concentrations fell steeply as the sampling point approached $140 \mathrm{~cm}$ from the nose. After the gelatin meal, however, the concentrations initially rose. Thus, after the two 
meals the concentrations tended to converge and had become similar by $140 \mathrm{~cm}$. These changes would be explained if $I_{5} \mathrm{~g}$ of milk protein and $1_{5} \mathrm{~g}$ of gelatin had stimulated the secretion of similar amounts of leucine, glutamate and methionine (as constituents of secreted proteins) and that which remained within the lumen at $140 \mathrm{~cm}$ was the residue of the secretions only. Gelatin appears to be an abnormal dietary protein in that it contains a high percentage of peptide bonds which are relatively resistant to

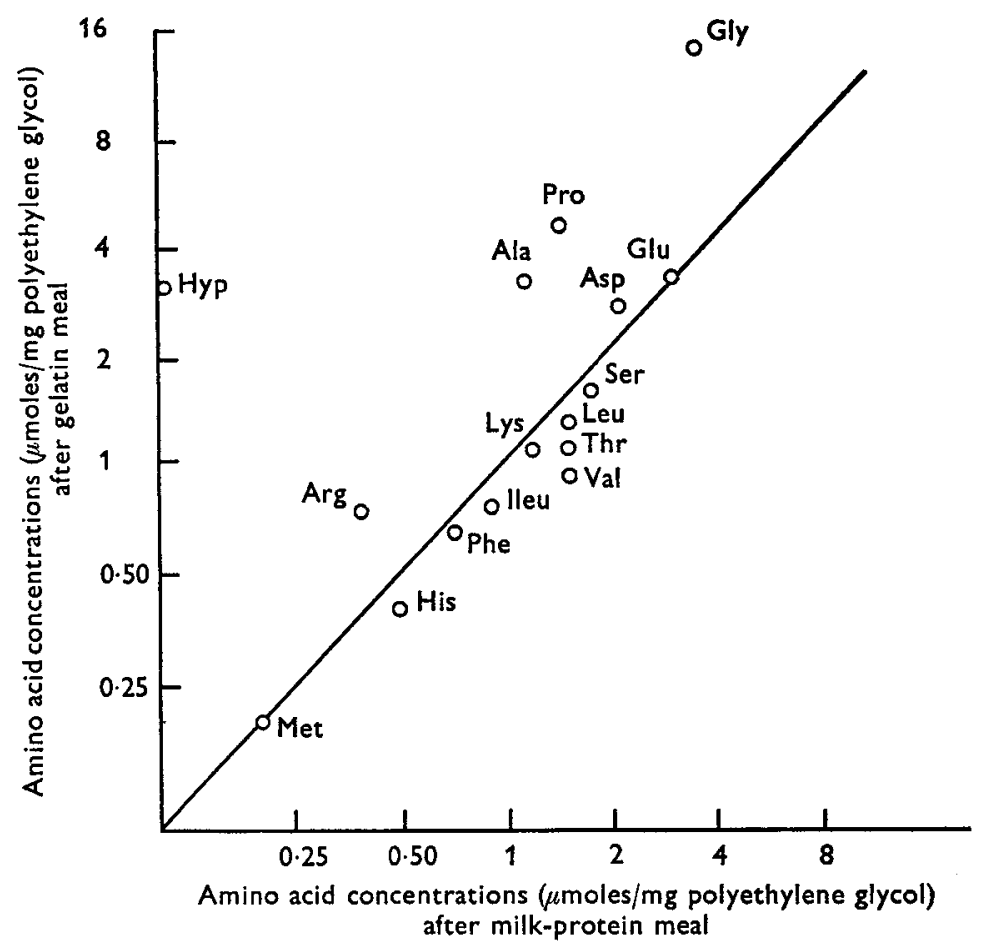

Fig. 2. Comparison of the amino acid concentrations in $3 \mathrm{~h}$ collections of intestinal contents collected from various levels of the intestine of young adults below $140 \mathrm{~cm}$ from the nose after the milk-protein meal and after the gelatin meal. The values after the milk-protein meal are the means from eight experiments conducted at intestinal levels from 150 to $245 \mathrm{~cm}$ from the nose; the values after the gelatin test meal are the means of two experiments at 185 and $194 \mathrm{~cm}$ from the nose. A log scale has been used.

enzymic hydrolysis (Chen, Rogers \& Harper, I962). Residues of this protein may, therefore, still be present in the lumen of the gut at a level by which the dietary protein has normally been absorbed. The apparent inconsistency of the results after the low-protein meal may have been due to a smaller stimulus to secretion by this meal.

(3) If digestion and absorption have been completed by $140 \mathrm{~cm}$ then the amino acid composition of the intestinal contents below this level should be independent of the nature of the dietary protein. In Fig. 2 the amino acid concentrations in intestinal contents from a level below $140 \mathrm{~cm}$ after the two protein meals are plotted against each other. A $\log$ scale has been used. With the exceptions of glycine, alanine, arginine, proline and hydroxyproline, the concentrations were very similar in both types of 
sample. This supports the suggestion that by this level the only residues of dietary protein which remain in the lumen are those which are resistant to enzymic hydrolysis.

The results reported in this paper, therefore, substantially confirm the conclusion by Borgström et al. (1957) that absorption of dietary protein is about $80 \%$ completed in the first $50-100 \mathrm{~cm}$ of jejunum.

\section{Dilution of dietary protein by endogenous protein}

The results do not indicate the large secretion of endogenous protein (a sixfold dilution of the meal) shown by Nakayama and his colleagues in experiments with dogs (Nakayama, Nakamura, Yamamoto \& Tamiya, 1960) and by Nasset \& Ju (1961) with both dogs and rats.

Estimates of endogenous secretion in the present experiments can be derived from the following.

(I) A comparison of the amino acid concentrations at I IO $\mathrm{cm}$ after the low-protein meal with those in the meal. At this level the total amino acid concentrations in the $3 \mathrm{~h}$ collection, excluding glycine, was ro $\mu$ moles/mg PEG. $3 \mu \mathrm{moles} / \mathrm{mg}$ PEG was the corresponding concentration in the test meal (Table 2). Therefore at least $7 \mu$ moles of amino acids per $\mathrm{mg}$ PEG had been derived from endogenous protein, i.e. $14 \mathrm{~m}$-moles had been added to the PEG-containing bolus (2 g PEG) during its passage to the sampling holes. $14 \mathrm{~m}$-moles of amino acids in the appropriate relative concentrations amounts to $\mathrm{r} \cdot 8 \mathrm{~g}$ protein. This is a minimum estimate and must be an underestimate of the actual endogenous protein because no account has been taken of absorption proximal to this level and because glycine from endogenous protein has not been included (a large part of the glycine measured in these experiments was probably derived from bile salts).

(2) The increase in total amino acid concentrations in the duodenum after the gelatin test meal amounted to $24 \mathrm{~m}$-moles or $3.5 \mathrm{~g}$ protein. Some absorption may already have occurred in the duodenum because the concentrations of hydroxyproline in the aspirated samples were lower than that in the meal. If $3.5 \mathrm{~g}$ protein had been secreted in response to the milk-protein meal then amino acids equivalent to approximately $25 \%$ of this meal had been absorbed in the duodenum. This estimate is, therefore, again an underestimate of the actual protein secretion.

(3) It has been suggested above that the dietary protein of the milk-protein meal had been digested and absorbed proximal to a level of $140 \mathrm{~cm}$ from the nose. The remaining amino acids must therefore be of endogenous origin and this gives an estimate of $58 \mathrm{~m}$-moles, or approximately $8 \mathrm{~g}$ protein.

The estimates of endogenous protein derived from these results range, therefore, from 2 to $8 \mathrm{~g}$. It seems probable that the latter estimate is nearer the true value. Secretion after the protein meals was greater than that after the low-protein meal, as can be seen by the relative concentrations of methionine and tyrosine in intestinal contents after these two types of meal. The methionine concentrations after the gelatin meal were approximately four times greater than in corresponding samples after the low-protein meal, although almost identical amounts were ingested in each instance (the methionine in the gelatin test meal was almost entirely derived from the 
cream). Some studies have shown that enzyme secretion, qualitatively and quantitatively, is directly related to the composition of the meal (Ben Abdeljlil \& Desnuelle, 1964; Snook \& Meyer, 1964).

This estimate amounts to only $50 \%$ of the protein ingested in the protein test meals and if this is near the correct value then amino acids equivalent to approximately $50 \%$ of the milk-protein test meal were absorbed in the duodenum.

Part of the discrepancy between the results in this paper and those of Nasset \& Ju (I96I) could be accounted for by differences in rates of gastric emptying. The gastric emptying times of $3 \mathrm{~h}$ in these experiments, with $50 \%$ of the meal leaving the stomach during the ist $\mathrm{h}$ (unpublished results), is consistent with other work in man using similar types of test meal (Hunt \& Spurrell, I95 I Borgström et al. I957). However, many workers have found that a period of up to $6 \mathrm{~h}$ is necessary for the whole of a test meal to leave the rat stomach (Geiger, Human \& Middleton, 1958; Rosenthal \& Nasset, 1958; Chen et al. 1962). Pancreatic secretions enter the gut 10-1 5 min after the ingestion of the meal and continue until the stomach is empty (Borgström et al. 1957). Slower gastric emptying in the dog and rat (or after a different type of meal in man) may increase the amount of endogenous protein by prolonging the secretion of digestive enzymes.

\section{Rates of absorption of the amino acid constituents of the test meal}

After a milk-protein meal the net absorption of the amino acids appeared to occur at rates dependent on the concentrations in the meal. Thus by the time the meal had reached an intestinal level of about $200 \mathrm{~cm}$ from the nose a net absorption of about $70 \%$ of glutamate and of arginine had occurred, amounting to $12 \mathrm{~m}$-moles glutamate and $1.5 \mathrm{~m}$-moles arginine. If the amount of intestinal secretions below the level of the duodenum may be assumed to be negligible in comparison with the amount of protein already in the lumen, then a comparison of amino acid concentrations at the upper level $(80-90 \mathrm{~cm})$ and the lower level $(245 \mathrm{~cm})$ will allow the determination of the absolute absorption of amino acids along this segment of gut. The percentage of each of these two amino acids which had been absorbed along this $150 \mathrm{~cm}$ of small intestine was again approximately $70 \%$, amounting to $3.9 \mu$ moles glutamate and $0.6 \mu$ moles arginine per mg PEG.

Arginine is absorbed rapidly and glutamate slowly from an equimolar solution of amino acids perfused through loops of small intestine, in vitro and in vivo (Gitler $\&$ Martinez-Rojas, 1964; Orten, 1963). When a solution of amino acids in the same relative concentrations as is found in egg albumen, with the concentration of glutamate three times that of arginine, is used, the rate at which absorption of glutamate occurs is markedly increased but the proportion absorbed is still much less than that of arginine (Gitler \& Martinez-Rojas, 1964).

If absorption of the amino acids had occurred at different rates in the experiments being described, the relative molar concentrations would have altered as samples were collected from progressively lower levels of the gut. Table 6 shows the amino acid concentrations, relative to leucine, in samples from various levels of the small intestine after the milk-protein meal. In the majority of cases there was an increase in the values 
with increasing distance from the nose and this was most marked for aspartate, threonine, serine and histidine. This may have been due to differences in rates of absorption (leucine is known to be absorbed rapidly from a mixture of amino acids) or it may have reflected the increasing influence of the endogenous protein. The relative molar concentrations in intestinal samples after the low-protein meal are included in the table for comparison. Above $130 \mathrm{~cm}$ the differences were not striking enough to suggest differences in the rates of absorption of the amino acid constituents of the milk-protein meal.

Table 6. Relative molar concentrations (leu $=\mathrm{I})$ of the amino acids in $3 \mathrm{~h}$ collections of intestinal contents taken from various levels of the small intestine of young adults after a milk-protein meal

(The right-hand column of the table shows the values in small intestinal contents from all levels after a low-protein meal)

Concentration in sample at distance from the nose of

\begin{tabular}{|c|c|c|c|c|c|c|c|c|c|c|}
\hline $\begin{array}{l}\text { Amino } \\
\text { acid }\end{array}$ & $81 \mathrm{~cm}$ & $86 \mathrm{~cm}$ & $99 \mathrm{~cm}$ & $109 \mathrm{~cm}$ & $130 \mathrm{~cm}$ & $169 \mathrm{~cm}$ & I $91 \mathrm{~cm}$ & $199 \mathrm{~cm}$ & $233 \mathrm{~cm}$ & $\begin{array}{l}110-24^{\circ} \\
\mathrm{cm}(\mathrm{LP})\end{array}$ \\
\hline Asp & $\mathbf{I} \cdot \mathbf{I} \mathbf{I}$ & $I \cdot I 5$ & $I \cdot 2 I$ & $I \cdot 24$ & $1 \cdot 36$ & I. 38 & $I \cdot 56$ & $I \cdot 62$ & $\mathrm{I} \cdot 45$ & $I \cdot 48$ \\
\hline Thr & 0.85 & 0.76 & 0.79 & $0.8 \mathrm{I}$ & 0.71 & 0.91 & $I \cdot 00$ & I.OO & 1.09 & 0.88 \\
\hline Ser & 0.94 & 0.83 & 0.85 & 0.90 & $1 \cdot 00$ & 0.91 & $I \cdot 19$ & $I \cdot 23$ & $\mathrm{I} \cdot 18$ & $1 \cdot 03$ \\
\hline Pro & $I .05$ & $I \cdot 00$ & 0.94 & $I \cdot I_{3}$ & 0.96 & 0.96 & $1 \cdot 00$ & $1 \cdot 00$ & $I \cdot 09$ & 0.88 \\
\hline Glu & $I \cdot 78$ & $I \cdot 8 I$ & $1 \cdot 91$ & $\mathrm{I} \cdot 87$ & $2 \cdot 08$ & I. 96 & $2 \cdot 12$ & $2 \cdot 23$ & $2 \cdot 09$ & $I \cdot 39$ \\
\hline Ala & 0.61 & 0.72 & 0.79 & 0.71 & 0.76 & 0.86 & 0.85 & 0.81 & 0.91 & 1.03 \\
\hline Val & 0.76 & $0.8 \mathrm{I}$ & 0.76 & 0.72 & 0.76 & 0.86 & 0.81 & 0.92 & $0.9 x$ & 0.97 \\
\hline Met & 0.18 & O.I 5 & 0.16 & 0.16 & 0.16 & 0.10 & 0.14 & 0.16 & 0.18 & O.II \\
\hline Ileu & 0.59 & 0.63 & $0.6 r$ & 0.55 & 0.60 & 0.67 & 0.63 & 0.69 & 0.64 & 0.66 \\
\hline Tyr & 0.30 & 0.33 & 0.30 & 0.32 & 0.35 & 0.30 & 0.36 & 0.39 & 0.36 & 0.40 \\
\hline Phe & 0.37 & 0.37 & 0.33 & 0.39 & 0.44 & 0.35 & 0.50 & 0.50 & $0 \cdot 36$ & 0.53 \\
\hline Lys & 0.74 & 0.72 & 0.76 & 0.84 & 0.80 & 0.67 & 0.87 & 0.92 & 0.75 & 0.63 \\
\hline $\mathrm{His}$ & 0.24 & 0.24 & 0.24 & 0.29 & 0.28 & 0.20 & 0.34 & 0.34 & 0.27 & 0.28 \\
\hline Arg & 0.26 & 0.24 & 0.25 & 0.29 & 0.26 & 0.22 & 0.30 & 0.32 & 0.31 & 0.39 \\
\hline
\end{tabular}

Each value for the samples after the milk-protein meal is the mean from two experiments done at adjacent levels. The values for the samples after the low-protein meal (LP) are the means from experiments at all levels.

The experiments described here, therefore, indicate that the rates of absorption of amino acid constituents from protein meals are different from the rates of those from amino acid mixtures.

This work was supported by a grant from the Distillers Co. Ltd. We are grateful to Trufood Ltd for a large amount of Humanized Trufood. We are also grateful to Professor R. H. Girdwood and to Professor R. B. Fisher for their encouragement. Miss L. Shearer provided technical assistance. This work was embodied in a thesis presented by S. Elizabeth Nixon for the degree of PhD in the University of Edinburgh, I967. 


\section{REFERENCES}

Ben Abdeljlil, A. \& Desnuelle, P. (1964). Biochim. biophys. Acta 81, 136.

Blankenhorn, D. H., Hirsch, J. \& Ahrens, E. H. Jr (1955). Proc. Soc. exp. Biol. Med. 88, 356.

Börgstrom, B., Dahlqvist, A., Lundh, G. \& Sjövall, J. (1957). F. clin. Invest. 36, 152 I.

Carlson, L. A. \& Wadstrom, L. B. (1959). Clinica chim. Acta 4, 197.

Chen, M. L., Rogers, Q. R. \& Harper, A. E. (1962). F. Nutr. 76, 235.

Geiger, E., Human, L. E. \& Middleton, M. J. (1958). Proc. Soc. exp. Biol. Med. 97, 232.

Gitler, C. \& Martinez-Rojas, D. (1964). In The Role of the Gastro-intestinal Tract in Protein Metabolism, p. 260. [H. N. Munro, editor]. Oxford: Blackwell Scientific Publications.

Hunt, J. N. \& Spurrell, W. R. (195 I). J. Physiol., Lond. I13, 157.

Hydén, S. (1 956). K. LanntbrHogsk. Annlr 22, 139.

Maddrey, W. C., Serebro, H. A., Marcus, H. \& Iber, F. L. (1967). Gut 8, 169.

Mawer, G. E. \& Nixon, E. (1969). Clin. Sci. 36, 463 .

Nakayama, K., Nakamura, T., Yamamoto, K. \& Tamiya, T. (1960). Gastroenterology 38, 946.

Nasset, E. S. \& Ju, J. S. (196i). F. Nutr. 74, 461.

Orten, A. (1 963). Fedn Proc. Fedn Am. Socs exp. Biol. 22, 1 103.

Rogers, Q. R., Chen, M. L., Peraino, C. \& Harper, A. E. (r 960). Y. Nutr. 72, 33 I.

Rosenthal, S. \& Nasset, E. S. (1958). \%. Nutr. 66, 9 I.

Sjövall, J. (1959). Acta physiol. scand. 46, 339.

Snook, J. T. \& Meyer, J. H. (1964). F. Nutr. 82, 409. 